\title{
TAPIZ LINGÜÍSTICO
}

\author{
Daniel Mena Márquez ${ }^{1}$ \\ María de los Ángeles Pupo Brinas ${ }^{2}$ \\ Mirtha Manzano Díaz ${ }^{3}$
}

\section{INTRODUÇÃO: INTERCÂMBIO INTERCULTURAL DE DOCENTES ${ }^{4}$}

No mês de julho de 2006, o Centro de Línguas e Interculturalidade da UFPR recebeu a visita de três professores cubanos - dois deles da Universidade de Ciego de Ávila e uma professora da Universidade de Havana. Estes professores, por força de acordos firmados entre suas instituições de origem e a UFPR, permaneceram no CELIN durante um mês, participando dos cursos intensivos como docentes. Em contra partida, o CELIN arcou com suas despesas de passagens aéreas, acomodação e alimentação. Durante o mês em que aqui estiveram, os professores se envolveram também em pesquisas em andamento e estabeleceram diversas trocas com alunos e professores do centro e com as famílias que os receberam.

Os três professores nos surpreenderam com o texto que reproduzimos a seguir. $\mathrm{O}$ teor do texto nos leva a pensar que a experiência de intercâmbio, em que pese os inúmeros pormenores envolvidos, tais como o choque cultural enfrentado tanto pelos professores visitantesn quanto por alguns alunos brasileiros, é absolutamente válida, na medida em que, ao conhecer a cultura do outro, refletimos sobre a nossa própria cultura e ampliamos o nosso conhecimento de mundo.

\footnotetext{
${ }^{1}$ Daniel Mena Márquez é Doutor; Professor de inglês na Universidade de Ciego de Ávila, Cuba.

${ }^{2}$ María de los Ángeles Pupo Brinas é Mestre em Lingüística Aplicada; Professora de português como língua estrangeira (PLE) na Faculdade de Línguas Estrangeiras da Universidade de Havana.

${ }^{3}$ Mirtha Manzano Díaz é doutora; Professora de inglês na Universidade de Ciego de Ávila, Cuba.

${ }^{4}$ Introdução escrita por Mariza Riva de Almeida, atualmente diretora do Centro de Línguas e Interculturalidade e Assessora de Relações Internacionas do Setor de Ciências Humanas, Letras e Artes da Universidade Federal do Paraná
} 
Trocamos o certo pelo duvidoso, o previsível pelo inesperado, mas, sobretudo, procuramos dar asas a todos os participantes do processo, asas da liberdade, que permitiram a cada um vivenciar a experiência de forma única.

O Centro de Línguas e Interculturalidade (CELIN) da Universidade Federal do Paraná é um centro onde culturas se fundem, onde a diversidade conforma o verdadeiramente humano, onde o calor e as cores confundem os esquemas temporais, onde a língua se unifica para ultrapassar os contextos mais estreitos e particulares. Nele não cabem as linhas, nem a forma. Não se trata de uma armadura, mas sim de diversidade de ritmos e de sotaques, é espaço autêntico e verdadeiramente humano para que os matizes pessoais encontrem a perfeita harmonia da vida.

Começamos a conhecer melhor o Brasil através do CELIN, especificamente, através do intercâmbio acadêmico entre as nossas universidades impulsionado pela diretora desse centro que ministrou na Universidade de Ciego de Ávila um curso sobre metodologia do ensino de língua inglesa. Posteriormente estabeleceram-se contatos na Universidade de Havana com os professores de português-língua estrangeira. Dessa forma surgiram os convênios de intercambio acadêmico entre nossas universidades pelo qual nos encontramos neste extraordinário país descobrindo e compartilhando momentos, sentimentos surpreendentes e contraditoriamente metafóricos.

Nosso $\boldsymbol{e} \boldsymbol{u}$ transitou entre a timidez e a surpresa, entre a introversão e a euforia, desde a alegria ao espasmo, desde a observação até o conhecimento. O $\boldsymbol{e u}$ singular é a expressão das impressões mais singelas, das crenças mais arraigadas, das aparências e mapas conceituais, de genes e contextos sociais pessoais - tudo é influenciado como que por uma conspiração cósmica para interpretar o entorno.

Nossa estadia foi breve, no entanto foi possível vivenciar experiências que impulsionaram captar do meio não apenas novos conhecimentos como também novas formas de entender o meio com todas as nuances, matizes e diferenças lingüísticas dos que convivemos nesse centro. Todo esse conjunto de semelhanças, diferenças, a interculturalidade é o que chamamos de tapiz linguístico. Fez aumentar o interesse pelo Brasil e sua cultura, pela língua e cultura de todos os intercambistas ali presentes. Permaneceu a vontade de trocar conhecimentos. Estávamos sedentos e famintos de conhecer a diversidade cultural que coabita no CELIN, todos os nossos sentidos estiveram em alerta constante.

O tempo é o pior inimigo do ser, mas é testemunha fiel e profunda do conhecimento do mesmo. Ele consome o efêmero, sanciona o supérfluo, aplaude a paciência, glorifica o sensato. O tempo é familiarização, é sistematização, é aprendizagem e sabedoria. Não é hora, 
nem dia, é uma sucessão de acontecimentos que aperfeiçoam nossas condutas, influencia nossas concepções, difunde nossa verdadeira essência.

Todo novo sempre nos provoca um sentimento de dúvida e de desafio, pois todo novo leva em sua medula, como a coluna vertebral, o poder do movimento, da dinâmica, do desenvolvimento. Não há nada tão novo que não se sustente sobre a base do tradicional, nem nada tão velho que não tenha valores transcendentais.

No entanto não é o novo o que mais nos atrai, nem o velho ao qual nos agarramos tanto. O que verdadeiramente nos transforma em seres temerários é o diferente, ainda que geralmente por comodidade sintamos preferências pela uniformidade e a sintonia visual, pelas fórmulas e a simplicidade. Aquilo que não se adequa à norma parece ultrapassar a fronteira do "normal", todo diferente costuma ser associado ao estranho.

Não sempre nossa natureza humana, sinônimo e resultado das relações sociais, nos prepara para a tolerância e a diferença, para a dúvida e a incongruência, para a aceitação e as nuances, para o equilíbrio e a diversidade.

Apesar de todos os mapas conceituais que conformam nossos mais internos pensamentos, os neurônios mais sábios e enérgicos alertam-nos do valor das particularidades e do lugar que elas ocupam no TODO. O CELIN nos permite perceber que como parte do TODO conformamos sua essência, que os claros-escuros, as cores e nuances individuais conformam o tecido complexo integrado no colorido e na beleza do tapiz intercultural o genericamente humano a que o centro aspira.

O Centro de Línguas oferece a oportunidade de reivindicarmos como seres humanos, a oportunidade de depurar nosso espírito, de ficar longe das nossas singularidades e transitar até caminhos universais, de esquecer as fronteiras do objetivo.

O CELIN oferece a oportunidade de unificar as subjetividades sociais, de perceber em cada partícula quântica o valor dos elementos que conformam a vida em geral, a transcendência da energia cósmica que imortaliza a memória do homem no tempo e no espaço.

Esse tem sido o objetivo essencial da constituição deste centro, alcançar através da palavra, (seja em sânscrito ou em latim, em russo ou em árabe, em inglês ou em alemão, em francês ou em espanhol como elemento particular da cultura), a imagem desejada, a representação de nossos pensamentos, a expressão de nossos planos internos matizados pelas características particulares de nossos contextos. O objetivo do centro está mais dirigido a compartilhar riquezas, aquelas que conformam nossas próprias identidades, compartilhar para 
receber, para crescer e darmos conta que são especificamente nossas diferenças o que nos universaliza.

O CELIN alcança esse objetivo, impacta socialmente, nos eleva culturalmente.

Mais uma vez, graças a este imemorável encontro, compreendemos hoje melhor do que nunca aquela frase de nosso poeta e patriota cubano José Marti: "Patria es humanidad".

\section{REFERÊNCIAS}

La Universidad en la Construcción de un mundo mejor. Dr. Fernando Vecino Alegret. $4^{\circ}$ Congresso Internacional de la Educación Superior. CH. 2004.

Mesa Redonda Instructiva. La lengua como símbolo de identidad de los pueblos y naciones. Jueves, 10 de Junio del 2004.CH. Cuba.

Mesa Redonda Internacional, 29 de Octubre del 2004. La Educación para la paz y la justicia social. Los avances en materia de educación que exhibe Cuba. La Habana, Cuba. 